\title{
COVID-19 patients in an university hospital; clinical characteristics and relationship with accompanying diseases, a prospective study
}

\section{Bir üniversite hastanesinde COVID-19 hastaları", klinik özellikler ve eşlik eden hastalıklar, prospektif bir çalışma}

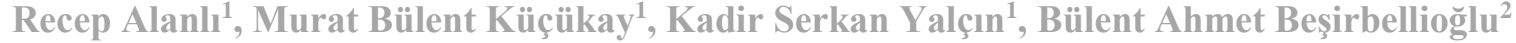

${ }^{1}$ Lokman Hekim University, Faculty of Medicine, Ankara Hospital, Department of Internal Diseases, Ankara, Turkey ${ }^{2}$ Lokman Hekim University, Faculty of Medicine, Ankara Hospital, Department of Infection Diseases, Ankara, Turkey

Corresponding author: Recep Alanl, MD, Lokman Hekim University, Faculty of Medicine, Ankara Hospital, Department of Internal Diseases, Ankara, Turkey

E-mail: recepalanli@gmail.com

Received/Accepted: June 23, 2020 / July 13, 2020

Conflict of interest: There is not a conflict of interest.

\section{SUMMARY}

Objective: The aim of this study is to inspect demographic information, laboratory test results and radiologic imaging studies of patients admitting to a pandemic hospital who were diagnosed Covid-19.

Method: In this single center, prospective observational study, 57 patients who were diagnosed Covid-19 were inspected between April and May 2020. Patients under 18 of age, and patients whose SARS-CoV-2 PCR test were negative were excluded.

Results: Mean age of patients was 44.9. Myalgia (61\%), high fever (58\%), cough $(54 \%)$ were most frequent complaints. Most frequent laboratory results were; increased CRP $(67 \%)$ and $\mathrm{LDH}(40 \%)$ levels and lymphopenia (27\%). One third of patients had accompanying diseases and most frequent accompanying disease was hypertension. Computed tomography imaging revealed bilateral involvement in $84 \%$ of patients having viral pneumonia. Conclusions: Patients having complaints of high fever, cough, myalgia and laboratory findings of increased CRP and LDH levels and lymphopenia should be carefully evaluated for Covid-19.

Keywords: Covid-19, fever, myalgia, C-reactive protein, lymphopenia, viral pneumonia.
(1D Recep Alanl
(D) Murat Bülent Küçükay
(D) Kadir Serkan Yalçın
(D) Bülent Ahmet Beşirbellioğlu

ORCID IDs of the authors:

R.A. 0000-0003-4663-1898

M.B.K. 0000-0003-3657-6565

K.S.Y. 0000-0002-8028-1070

B.A.B. 0000-0003-2172-0616

\section{ÖZET}

Amaç: Bu çalışmanın amacı bir pandemi hastanesine başvuran ve COVID-19 tanı konulan hastaların demografik verilerini, laboratuvar test neticelerini ve redyolojik görüntüleme çalışmalarını incelemektir.

Yöntem: Tek merkezde, prospektif gözlemsel bu çalışmada Nisan ve Mayıs 2020 tarihleri arasında pandemi hastanesine başvuran ve COVID-19 tanısı konulan 57 hasta incelenmiştir. SARS-CoV-2 PCR testi negatif saptanan veya 18 yaş altında olan hastalar çalışma dişı tutulmuştur.

Bulgular: Hastaların ortalama yaşı 44,9 idi. En sık gözlenen yakınmalar sırasıyla kas ağrısı (\%61 ), yüksek ateş (\%58) ve öksürük (\%54) olarak saptanmıştır. En sık saptanılan anormal laboratuvar değerleri CRP (\%67) ve LDH (\%40) yükselmesi ve lenfopeni (\%27) olarak gözlenmiştir. Hastaların üçte birinde eşlik eden hastalık mevcuttu ve en sık saptanan eşlik eden hastalık hipertansiyon (\%23) idi. Bilgisayarlı tomografide viral pnömoni saptanan hastaların $\% 84$ 'ünde bilateral tutulum vard1. 


\section{INTRODUCTION}

A rapidly spreading new corona virus infection started in Wuhan City, China was reported as corona virus disease 19 (Covid-19) ${ }^{1}$. Covid-19 is now a devastating pandemic. First case was reported at March 11, 2020 in Turkey. Studies about epidemiology and clinical characteristics of disease are still ongoing. Progress of disease shows great differences in patients, while some patients have almost no or few symptoms, others may experience serious respiratory difficulties, renal or cardiac problems ${ }^{2}$.

Most frequent symptoms of Covid-19 are high fever (over 38 Celsius), dry cough, weakness, nasal congestion, sore throat and diarrhea ${ }^{3}$. Majority of cases have few symptoms and prognosis is very good. Few patients develop serious viral pneumonia, respiratory failure or even acute respiratory distress syndrome. In some patients multi organ failure may be seen ${ }^{4,5}$.

Thorax computed tomography (CT) may be used for diagnosis and follow up of Covid-19. Most frequent finding in $\mathrm{CT}$ is peripheral ground glass opacifications in lower lobes ${ }^{6}$.

Advanced age, laboratory abnormalities like elevated D-dimer levels, lymphopenia and thrombocytopenia may predict poor prognosis ${ }^{7,8}$. But pathophysiology of the disease is still unrevealed and there is necessity for new parameters in predicting poor prognosis.

Most of the published literature about Covid-19 are reported from China ${ }^{2-7}$. Whether these data are consistent with cases in Turkey is not known yet.

The aim of this study is to inspect demographic information, laboratory test results and radiologic imaging studies of patients admitting to hospital who were diagnosed Covid-19.

\section{MATERIAL AND METHODS}

This is a single center, prospective observational cohort study conducted in an university hospital in Ankara city of Turkey. Fifty seven patients who were diagnosed Covid-19 were inspected between
April and May 2020. Patients admitted to emergency unit or outpatient clinics with weakness, dry cough, sore throat, high fever (over 38 Celsius), dyspnea, headache and myalgia and who had positive severe acute respiratory syndrome corona virus 2 (SARS-CoV-2) polymerase chain reaction (PCR) test result were included. Patients under 18 of age, and patients whose Covid-19 PCR test negative were excluded. This study was approved by Commission of Scientific Research Studies on COVID-19 (https://bilimselarastirma.saglik.gov.tr 2020-0509T22_40_18) and the local ethics committee (Approval no: 2020029). As soon as patients got positive PCR results, informed written consent was obtained from all of the patients participated in the study.

Demographic information, laboratory test results and radiologic imaging studies and clinical observation information was noted. Accompanying diseases, contact status with Covid-19 patient, symptoms for Covid-19 were questioned and noted. PCR testing for Covid-19, complete blood count (lymphocyte, neutrophil, thrombocyte counts), alanine aminotransferase (ALT), aspartate aminotransferase (AST), creatinine, lactic dehydrogenase (LDH), creatinine kinase (CK), Creactive protein (CRP), ferritin, d-dimer, prothrombin international normalization ratio (PTINR) and troponin I levels and thorax CT, when necessary for that patient, were inspected. Complete blood counts were analyzed by Sysmex $\mathrm{XN}-1000$ (USA) as 22 parameters. ALT, AST, creatinine, LDH, CK, d-dimer, CRP tests were analyzed by Roche Hitachi Cobas 501 (Switzerland). Ferritin, troponin I and procalcitonin tests were anaylzed by Roche Hitachi Cobas 601 (Switzerland). PT-INR was analyzed by Tokra Novae (Turkey).

Nasal and/or oropharyngeal swap specimens of patients admitted to hospital with Covid-19 suspicion were placed in viral transport medium and sent to reference laboratory for real time reverse transcription polymerase chain reaction 
(rRT-PCR) testing. Covid-19 was diagnosed after detection of specific viral RNA sequences with nucleic acid amplification test (NAAT).

SPSS for Windows 25.0 statistical software package (SPSS Inc., Chicago, IL, USA) was used for statistical analysis of the data. The results of all the parameters of the cases was given as the mean \pm standard deviation and $\mathrm{p}$ value $<0.05$ was considered statistically significant.

\section{RESULTS}

Study was conducted with 57 patients; 29 (51\%) were male and $28(49 \%)$ were female. Mean age of patients was $44.9 \pm 16.44$ (males $45.10 \pm 3.0$, females $44.71 \pm 3.0$ ) years. On follow up four patients were treated in intensive care unit and only one patient died. Mortality ratio was $1.7 \%$. Thirty eight (67\%) patients had no accompanying disease. Twelve patients had one, five patients had two, two patients had three accompanying chronic disease. Most frequently seen accompanying disease was hypertension (13 patients). Six patients had diabetes, two had coronary artery disease, two had malignancies, one had chronic pulmonary obstructive disease and one had renal failure. One patient was pregnant for 12 weeks. Twenty eight (49\%) patients had a contact history with confirmed Covid-19 patient, one patient had contact history with people coming from abroad.

Myalgia (61\%), high fever (58\%), cough (54\%) were most frequent complaints. Six patients (11\%) had no complaints (asymptomatic). Complaints and frequencies were shown in Table 1.

Most frequent laboratory results were; increased CRP (67\%) and LDH (40\%) levels and lymphopenia (27\%). Laboratory results of patients and ratio of abnormal results were shown in Table 2.

Chest $\mathrm{x}$-rays were obtained in seven patients in whom suspicion for pneumonia were low. Reminder of patients were evaluated with thorax CT. After evaluation of imaging studies; 25 (44\%) had no radiologic findings of pneumonia and 32 (56\%) had pneumonia. In five patients $(15.6 \%)$ pneumonia was unilateral and bilateral in remaining 27 (84.4\%) patients.

Table I: Complaints of patients and frequencies

\begin{tabular}{|l|c|}
\hline Symptom & Frequency (ratio) \\
\hline Myalgia & $35(61 \%)$ \\
\hline Fever & $33(58 \%)$ \\
Cough & $31(54 \%)$ \\
\hline Headache & $30(52 \%)$ \\
\hline Sore throat & $25(44 \%)$ \\
\hline Fatigue & $19(33 \%)$ \\
\hline Nausea & $16(28 \%)$ \\
\hline Dyspnea & $16(28 \%)$ \\
\hline Nasal congestion & $15(27 \%)$ \\
\hline Loss of taste sensation & $15(26 \%)$ \\
\hline Diarrhea & $14(25 \%)$ \\
\hline Abdominal pain & $12(21 \%)$ \\
\hline Vomiting & $7(12 \%)$ \\
\hline Itching and burning at eyes & $4(7 \%)$ \\
\hline
\end{tabular}


Table II: Laboratory Results of patients and ratio of abnormal results

\begin{tabular}{|c|c|c|}
\hline Neutrophil Count $\left(\times 10^{9} / \mathrm{L}\right)$ & $\begin{array}{c}\text { Mean (Reference Rage) } \\
3.78 \pm 1.80(2.0-7.0)\end{array}$ & Ratio \\
\hline Neutrophil Count $>7$ & & $3.00 \%$ \\
\hline Lymphocyte count (x109/L) & $1.64 \pm 0.80(1.2-3.5)$ & \\
\hline Lymphocyte count $<1,2$ & & $27.00 \%$ \\
\hline Platelet count $\left(\mathrm{x} 10^{9} / \mathrm{L}\right)$ & $236 \pm 79(150-450)$ & \\
\hline Platelet count $<150$ & & $7.00 \%$ \\
\hline Creatine kinase (U/L) & $138.83 \pm 92(26-192)$ & \\
\hline Creatine kinase $>192$ & & $10.00 \%$ \\
\hline Alanine aminotransferase (U/L) & $26.43 \pm 16(0-34)$ & \\
\hline Alanine aminotransferase $>34$ & & $17.00 \%$ \\
\hline Aspartate aminotransferase (U/L) & $26.22 \pm 16(0-33)$ & \\
\hline Aspartate aminotransferase $>33$ & & $14.00 \%$ \\
\hline Creatinine $(\mu \mathrm{mol} / \mathrm{L})$ & $74.20 \pm 22(61-106)$ & \\
\hline Creatinine > 106 & & $5.00 \%$ \\
\hline Lactate dehydrogenase (U/L) & $229.43 \pm 112(135-214)$ & \\
\hline Lactate dehydrogenase $>214$ & & $40.00 \%$ \\
\hline C-reactive Protein (mg/L) & $27.72 \pm 11(0-5)$ & \\
\hline C-reactive Protein $>5$ & & $67.00 \%$ \\
\hline Ferritin $(\mu \mathrm{g} / \mathrm{L})$ & $288.94 \pm 346(18-200)$ & \\
\hline Ferritin $>200$ & & $20.00 \%$ \\
\hline D-dimer (nmol/L) & $2595 \pm 421(0-2738)$ & \\
\hline D-Dimer > 2738 & & $14.00 \%$ \\
\hline PT-INR ${ }^{\dagger}$ & $1.11 \pm 0.49(0.8-1.2)$ & \\
\hline PT-INR ${ }^{\dagger}>1.2$ & & $16.00 \%$ \\
\hline Troponin I $(\mu \mathrm{g} / \mathrm{L})$ & $0.26 \pm 0.7(0-0.3)$ & \\
\hline Troponin I >0.3 & & $4.00 \%$ \\
\hline Procalcitonin (ng/ml) & $0.19 \pm 0.54(0-0.5)$ & \\
\hline Procalcitonin $>0.5$ & & $3.00 \%$ \\
\hline
\end{tabular}

$\dagger$ Prothrombin Time International Normalization Ratio

\section{DISCUSSION}

In this study, patients who had positive results for Covid-19 PCR testing were inspected. Myalgia, high fever, cough were most frequent complaints and increased CRP, LDH levels and lymphopenia were most frequent laboratory findings. One third of patients had accompanying diseases and most frequent accompanying disease was hypertension.

Mean age for patients were reported as 63 in a study from USA and 56 in another from China ${ }^{9,10}$. 
In this study mean age was 45 , relatively low compared to these studies. This may be explained by older people's (who are above 65 years) staying at home with government obligation and also by people's mean age being lower than USA and China in Turkey.

In a study with 44672 Covid-19 patients, mortality was $2.3 \%$ in China ${ }^{11}$. Mortality rate was reported as $8 \%$ in patients hospitalized for Covid-19 disease in Iran ${ }^{12}$. In a study with 5700 patients reported from USA, mortality was 5\% [9]. Mortality because of Covid-19 is greatly varying from country to country. In mid March $7.2 \%$ mortality rate was reported from Italy ${ }^{13}$. Meanwhile Korea reported mortality as low as $0.9 \%{ }^{14}$. Korean people's mean age was about 40 years in Covid-19 disease, but Italian patients' mean age were 64 years and this great difference might result in such a change in mortality rates. In this reported study mortality rate was low as $1.7 \%$ and this was explained by relatively young patient age and lower existence of accompanying diseases.

A study reported from Italy inspected 355 patients that died because of Covid-19. There were 2.7 accompanying disease for each patient and only three patients did not have any accompanying disease ${ }^{13}$. Another study reported $46 \%$ of Covid19 patients had at least one accompanying disease ${ }^{10}$. In this reported study only $33 \%$ of all Covid- 19 patients had an accompanying disease.

There was an ongoing SARS-Cov-2 contagion in a cruise ship; all people on board has been tested by PCR for Covid-19, half of the people infected were aysmptomatic at time of positive result but on follow up only $18 \%$ remained asymptomatic (real asymptomatic patients) ${ }^{15}$. In a study reported from India, 39\% of participants had an history of contact with confirmed Covid-19 patient ${ }^{16}$. In this report, half of the participants had contact history and asymptomatic patient ratio was $11 \%$. This low value compared to other studies might be explained by lower hospital admission of asymptomatic people who may have Covid-19.

A study from China reported symptoms of patients as; fever (99\%), weakness (70\%), cough (59\%), loss of appetite (40\%), myalgia (35\%), dyspnea (31\%) and sputum (27\%) [10]. Another study reported $44 \%$ of participants having high fever in Covid-19 disease ${ }^{15}$. In a study from Italy, $34 \%$ of patients had loss of taste and smell sensations ${ }^{17}$. Most frequent symptoms reported from a study in
USA were; cough (79.4\%), fever (77.1\%), dyspnea $(56.5 \%)$, myalgia $(23.8 \%)$, diarrhea $(23.7 \%)$ and nausea-vomiting $(19.1 \%)^{18}$. In this study most frequently seen symptoms were myalgia, high fever and cough respectively (Table 1). Under the light of literature it can be pointed that frequency of high fever greatly differs according to the country the disease is ongoing and time and course of contagion ${ }^{10,15}$. Probably at the beginning of pandemic, Covid-19 disease concept was not fully understood. So some patients who had myalgia, weakness and non specific cough symptoms were not tested for Covid-19. But with progression of pandemic, disease concept was fulfilled by many countries and patients who did not have high fever or specific symptoms for disease were also tested for Covid-19.

Lymphopenia, increased levels of LDH, CRP, PTINR, d-dimer and CK were reported in Covid-19 patients ${ }^{4,10,19,20}$. Procalcitonin levels were reported to be normal and increased levels were associated to bacterial infections ${ }^{21}$. In this reported study, most frequent abnormal laboratory findings were increased CRP and LDH levels and decreased lymphocyte counts. Increase in troponin I, procalcitonin, creatinin levels and neutrophil counts were seldom and very few patients had thrombocytopenia.

Thorax computed tomographies of 101 Covid-19 PCR positive patients were inspected in a study from China and $82 \%$ were reported to have bilateral involvement ${ }^{6}$. This study also reports a similar rate of $84 \%$ for bilateral involvement in thorax computed tomographies.

This study has some limitations. Only PCR positive patients were enrolled to study. And patients whose clinical condition reminded Covid-19 but tested negative in PCR were not enrolled. Since this study has relatively few participants and was conducted in a single center, it may nor reflect general population of country.

\section{CONCLUSION}

In conclusion; patients having complaints of high fever, cough, myalgia and laboratory findings of increased CRP and LDH levels and lymphopenia should be carefully evaluated for Covid-19.

\section{Acknowledgements}

Authors of this study thank to Mr. Fatih ACIKGOZ for statistical analysis and advices. 


\section{Conflict of Interest}

The authors report no conflict of interest

\section{REFERENCES}

1. World Health Organization [Internet]. Rolling updates on coronavirus disease (COVID-19). 2020 [Cited 2020, June 1]. Available from: https://www.who.int/emergencies/diseases/novelcoronavirus-2019/events-as-they-happen

2. Chen N, Zhou M, Dong X, Qu J, Gong F, Han $\mathrm{Y}$, et al. Epidemiological and clinical characteristics of 99 cases of 2019 novel coronavirus pneumonia in Wuhan, China: a descriptive study. The Lancet [Internet]. Elsevier BV; 2020 Feb;395(10223):507-13. Available from: http://dx.doi.org/10.1016/s01406736(20)30211-7.

3. Wu J, Wu X, Zeng W, Guo D, Fang Z, Chen L, et al. Chest CT Findings in Patients With Coronavirus Disease 2019 and Its Relationship With Clinical Features. Investigative Radiology [Internet]. Ovid Technologies (Wolters Kluwer Health); 2020 May;55(5):257-61. Available from: http://dx.doi.org/10.1097/rli.0000000000000670.

4. Huang C, Wang Y, Li X, Ren L, Zhao J, Hu Y, et al. Clinical features of patients infected with 2019 novel coronavirus in Wuhan, China. The Lancet [Internet]. Elsevier BV; 2020 Feb;395(10223):497-506. Available from: http://dx.doi.org/10.1016/s0140-6736(20)30183-5.

5. Guan W, Ni Z, Hu Y, Liang W, Ou C, He J, et al. Clinical Characteristics of Coronavirus Disease 2019 in China. New England Journal of Medicine [Internet]. Massachusetts Medical Society; 2020 Apr 30;382(18):1708-20. Available from: http://dx.doi.org/10.1056/nejmoa2002032.

6. Zhao W, Zhong Z, Xie X, Yu Q, Liu J. Relation Between Chest CT Findings and Clinical Conditions of Coronavirus Disease (COVID-19) Pneumonia: A Multicenter Study. American Journal of Roentgenology [Internet]. American Roentgen Ray Society; 2020 May;214(5):1072-7. Available from: http://dx.doi.org/10.2214/ajr.20.22976.

7. Zhou F, Yu T, Du R, Fan G, Liu Y, Liu Z, et al. Clinical course and risk factors for mortality of adult inpatients with COVID-19 in Wuhan, China: a retrospective cohort study. The Lancet [Internet]. Elsevier BV; 2020 Mar;395(10229):1054-62.
Available from: http://dx.doi.org/10.1016/s01406736(20)30566-3.

8. Brogly N, Devos P, Boussekey N, Georges H, Chiche A, Leroy O. Impact of thrombocytopenia on outcome of patients admitted to ICU for severe community-acquired pneumonia. Journal of Infection [Internet]. Elsevier BV; 2007 Aug;55(2):136-40. Available from: http://dx.doi.org/10.1016/j.jinf.2007.01.011.

9. Richardson S, Hirsch JS, Narasimhan M, Crawford JM, McGinn T, Davidson KW, et al. Presenting Characteristics, Comorbidities, and Outcomes Among 5700 Patients Hospitalized With COVID-19 in the New York City Area. JAMA [Internet]. American Medical Association (AMA); 2020 May 26;323(20):2052. Available from: http://dx.doi.org/10.1001/jama.2020.6775.

10. Wang D, Hu B, Hu C, Zhu F, Liu X, Zhang J, et al. Clinical Characteristics of 138 Hospitalized Patients With 2019 Novel Coronavirus-Infected Pneumonia in Wuhan, China. JAMA [Internet]. American Medical Association (AMA); 2020 Mar 17;323(11):1061. Available from: http://dx.doi.org/10.1001/jama.2020.1585.

11. Wu Z, McGoogan JM. Characteristics of and Important Lessons From the Coronavirus Disease 2019 (COVID-19) Outbreak in China. JAMA [Internet]. American Medical Association (AMA); 2020 Apr 7;323(13):1239. Available from: http://dx.doi.org/10.1001/jama.2020.2648.

12. Nikpouraghdam M, Jalali Farahani A, Alishiri G, Heydari S, Ebrahimnia M, Samadinia H, et al. Epidemiological characteristics of coronavirus disease 2019 (COVID-19) patients in IRAN: A single center study. Journal of Clinical Virology [Internet]. Elsevier BV; 2020 Jun;127:104378. Available from: http://dx.doi.org/10.1016/j.jcv.2020.104378.

13. Onder G, Rezza G, Brusaferro S. Case-Fatality Rate and Characteristics of Patients Dying in Relation to COVID-19 in Italy. JAMA [Internet]. American Medical Association (AMA); 2020 Mar 23; Available from: http://dx.doi.org/10.1001/jama.2020.4683.

14. KCDC [Internet]. Updates on COVID-19 in Korea. March 14, 2020 [Cited 2020, March 14]. Available from https://www.cdc.go.kr/board/board.es?mid=a3040 $2000000 \&$ bid $=0030$. 
15. Mizumoto K, Kagaya K, Zarebski A, Chowell G. Estimating the asymptomatic proportion of coronavirus disease 2019 (COVID-19) cases on board the Diamond Princess cruise ship, Yokohama, Japan, 2020. Eurosurveillance [Internet]. European Centre for Disease Control and Prevention (ECDC); 2020 Mar 12;25(10). Available from: http://dx.doi.org/10.2807/15607917.es.2020.25.10.2000180.

16. Gupta N, Praharaj I, Bhatnagar T, Vivian Thangaraj JW, Giri S, Chauhan H, et al. Severe acute respiratory illness surveillance for coronavirus disease 2019, India, 2020. Indian J Med Res. 2020 Mar;151(2 \& 3):236-40. Available from:

http://dx.doi.org/10.4103/ijmr.IJMR_1035_20.

17. Giacomelli A, Pezzati L, Conti F, Bernacchia D, Siano M, Oreni L, et al. Self-reported Olfactory and Taste Disorders in Patients With Severe Acute Respiratory Coronavirus 2 Infection: A Crosssectional Study. Clinical Infectious Diseases [Internet]. Oxford University Press (OUP); 2020 Mar 26; Available from: http://dx.doi.org/10.1093/cid/ciaa330.
18. Goyal P, Choi JJ, Pinheiro LC, Schenck EJ, Chen R, Jabri A, et al. Clinical Characteristics of Covid-19 in New York City. New England Journal of Medicine [Internet]. Massachusetts Medical Society; 2020 Jun 11;382(24):2372-4. Available from: http://dx.doi.org/10.1056/nejmc2010419.

19. Wang Y, Wang Y, Chen Y, Qin Q. Unique epidemiological and clinical features of the emerging 2019 novel coronavirus pneumonia (COVID-19) implicate special control measures. Journal of Medical Virology [Internet]. Wiley; 2020 Mar 29;92(6):568-76. Available from: http://dx.doi.org/10.1002/jmv.25748.

20. Bai Y, Yao L, Wei T, Tian F, Jin D-Y, Chen L, et al. Presumed Asymptomatic Carrier Transmission of COVID-19. JAMA [Internet]. American Medical Association (AMA); 2020 Apr 14;323(14):1406. Available from: http://dx.doi.org/10.1001/jama.2020.2565.

21. Hassan SA, Sheikh FN, Jamal S, Ezeh JK, Akhtar A. Coronavirus (COVID-19): A Review of Clinical Features, Diagnosis, and Treatment. Cureus [Internet]. Cureus, Inc.; 2020 Mar 21; Available from: http://dx.doi.org/10.7759/ cureus. 7355 . 